\title{
sciendo
}

Research Article

(c) 2019 Stapa et.al. This is an open access article licensed under the Creative Commons Attribution-NonCommercial-NoDerivs License (http://creativecommons.org/licenses/by-nc-nd/3.0/).

\section{Attitudes and Motivation of the Young Generation towards the Palm Oil Industry}

\author{
Prof. Dr. Siti Hamin Stapa \\ Dr. Kesumawati A Bakar \\ Ms. Fuzirah Hashim \\ Universiti Kebangsaan Malaysia
}

Doi: $10.2478 / \mathrm{mjss}-2019-0012$

\begin{abstract}
Malaysia is currently one of the largest producers and exporters of palm oil in the world. Despite the strength and vast potential of our palm oil industry, engaging the youth in this industry is a challenging task as most perceive the industry and agriculture unattractive as a career, without realising the importance of the sector in their everyday lives. Furthermore, the development of sectors such as ecommerce, digital technology and real estate is a compounding factor behind the decline of interest among the younger FELDA generation. The present study is designed to examine the attitudes and motivation of young FELDA generation towards the palm oil industry. A simple random sampling technique was adopted to select 50 working respondents from the age of 22-40 at 4 FELDA settlements. Questionnaire was distributed for primary data collection, where a four-point Likert scale was used to examine differences in attitudes and motivation towards 64 statements regarding aspects ranging from working conditions to promotion opportunities. The findings point to an overall positive attitude towards all aspects of the industry. The highest mean is revealed in the area of social status, with the majority feeling respected and proud to be a part of the palm oil community. In general, the majority of the respondents display positive attitude and motivation towards the palm oil industry. Based on the findings we would recommend trainings to empower FELDA youths to take advantage of the expanding industry and to claim their space in the palm oil sector.
\end{abstract}

Keywords: attitude; motivation; youths; palm oil industry; agriculture

\section{Introduction}

On July 1, 1956, Federal Land Development Authority (FELDA) was acclaimed under the Land Development Ordinance of 1956. It was recognized for the development of land and relocation (felda.net.my) to eradicate poverty through the plantation of oil palm and rubber. FELDA's main role is to execute projects of land development and agricultural activities, for industrial and commercial social economy. Currently, FELDA continues its function by providing adequate and modern facilities to ensure that future generation will be able to uprade their socio-economic and quality of life. With this, various economic activities can be generated and the gap between urban and small urban areas can be bridged.

The first oil palm cultivation was implemented at Felda Taib Andak in 1961 to address rural poverty by providing 'land for the landless, and jobs for the jobless'. The introduction has managed to help eradicate poverty of a few thousand people (The Star Online, 2017). The latest statistics has given Malaysia a dominant position in the palm oil industry where it has successfully produced $39 \%$ of palm oil world production and $44 \%$ of world exports. However, despite the abundance and potential of this commodity, human resources is seen to be the restricting factor that could 
jeopardize the sustainability of the palm oil industry. This is not surprising as engaging youth in agriculture, specifically in the palm oil industry is an arduous task as many youth are not interested to embark themselves in this industry. Agriculture is not viewed as an attractive alternative to other work sectors like manufacturing, public and private sector employment. This is mainly because of the popular belief that the agricultural sector is a rough job with low salaries and does not promise a direct good future for the people (Abdul Aziz \& Norhlilmatun, 2013).

In May 2017, statistics from the Malaysia Palm Oil Board (MPOB) revealed that the number of workers in the oil palm sector in Malaysia was 428,000 where $77 \%$ of them were foreign workers. This is because the locals are less interested in joining the plantation sector even though it provides a wide range of job opportunities. One of the reasons underlying the lack of interest and participation of locals is the labour-intensive nature of the palm oil industry. A study by Roslina et al (2016) reported that negative perception the local youths hold towards the working environment as unappealing and dirty pushes them further away from working in the industry. According to a survey by Malaysia Human Resource Statistics, the majority of local youths preferred to work in manufacturing and retail sector and most of them chose agriculture and plantation sector as their third choice (Mohammad Amizi et.al, 2016). However, is this negativity reflected in the attitudes of youths who are already a part of the palm oil industry and community? This article will report findings from a research that examined the attitude and motivation of young FELDA generation towards palm oil industry.

\section{Theory of Attitude and Motivation}

Many attitude theories assert that attitude encompasses three components; namely cognition, affect and behavioral tendencies. Cognition includes beliefs, opinions, knowledge or information held by a person towards an object; the indicators involve verbal and non-verbal attitudinal expressions or reactions. The affective component is the emotional element of an attitude involving positive or negative expression of feelings towards an object. Lastly, the behavioral tendencies refer to 'behavioral inclinations, plans, intentions and commitments, as well as overt motor acts involving the attitude object' (Ajzen, 1993, p.42).

Gardner proposed that 'attitude is an evaluative reaction to some referent or attitude object, inferred on the basis the individual's beliefs or opinions about the referent.' (1985, P. 9). In a similar vein, Martin and White (2003) defines attitude as resources used for expressing positive or negative evaluation of human behaviour, processes, animate and inanimate objects, states of affairs and emotions. Baker (1988) summarized the main characteristics of attitude as being both cognitive (thinking) and affective (emotion) and vary in degree of favorability/unfavorability. They are learnt and not inherited, but can change according to experience. Attitudes can influence a person to act in a particular way, but the relationship between attitudes and actions is a weak one. In this study, we refer to attitude as an individual's positive or negative reaction or disposition to an idea, object, person or situation associated with aspects of the palm oil industry such as working environment, management, labour issues and remuneration.

Motivation is a very important factor in ensuring productivity and innovation within an organisation (Bloisi et al., 2003). Arnold et al. (1991) established three components of motivation that influence people to behave in positive ways namely 1) direction: the aim or purpose of a person 2) effort: the determination of the person and 3) persistence: the level of perseverance a person has.

Mullins (2005) identified four common aspects underlying the definition of motivation. Firstly, motivation is a phenomenon unique to every individual. Secondly, it is usually intentional and assumed to be within the individual's control. Thirdly, motivation is multidimensional where two factors of greatest importance are what drives people and whether it pushes them to engage in desired behaviour. Finally, motivation concerns action rather than behaviour or performance, as well the internal and external factors which influence a person's choice of action.

Studies on motivation started decades ago investigating the way our behaviour is motivated. The basic perspective on motivation postulates that our needs or wants cause us to do certain things (behavior) to satisfy those desires. Motivation therefore refers to goal-directed behavior (cf. Heckhausen, 1991) and generally, a motivated individual will demonstrate many behaviors, 
feelings, cognitions, etc., than an unmotivated individual (A.-M.Masgoret \& R.C.Gardner, 2002).

There are two types of motivation: intrinsic motivation and extrinsic motivation. Coon \& Mitterer (2010) state that intrinsic motivation refers to an action that is carried out without any obvious external rewards. The activity is perceived as an opportunity to learn, explore and actualize our potentials. It is also performed for personal satisfaction or pleasure. Essentially, intrinsic motivation is a behaviour based on cognitive and affective processes. Intrinsic motivation usually involve the satisfaction in helping other people. This type of motivation can be seen in cases where comparison is made between their own favorable performance to that of others. Those with intrinsic motivation find motivation within themselves. They are keen to learn more in the areas where they found that they are intrinsically motivated. Intrinsic motivation is believed to last longer, more persistent, and enhances achievement compared to extrinsic motivation. Extrinsic motivation refers to activities that are performed for external or psychological rewards. Example of external reward is financial, while example of psychological reward could be status and recognition in nature (Brown, 2007). The means to an end, for example acceptance or monetary gains, thus contribute to the drive of this type of motivation. In another words, it does not come from within a person. The difference between intrinsic and extrinsic motivations thus lies in the motive behind each action.

Motivation can be divided into two types: positive and negative. Positive motivation refers to "the type of motivation a person feels when he expects rewards in the immediate future. The expectation of that reward, and visualizing yourself when you have the reward, is what motivates you. On the contrary, negative motivation is the type of feeling a person gets when he expects punishment. This occurs when an action is taken to avoid dismissal, demotion or group disapproval". (Kashyap 2017 https://www.linkedin.com/pulse/positive-negative-motivation).

According to Kashyap (2017) both positive and negative motivations have internal and external aspects (see Figure 1). Both kind of motivation can lead to the same result however overuse of negative motivation may result in problems such as resentment towards co-workers.

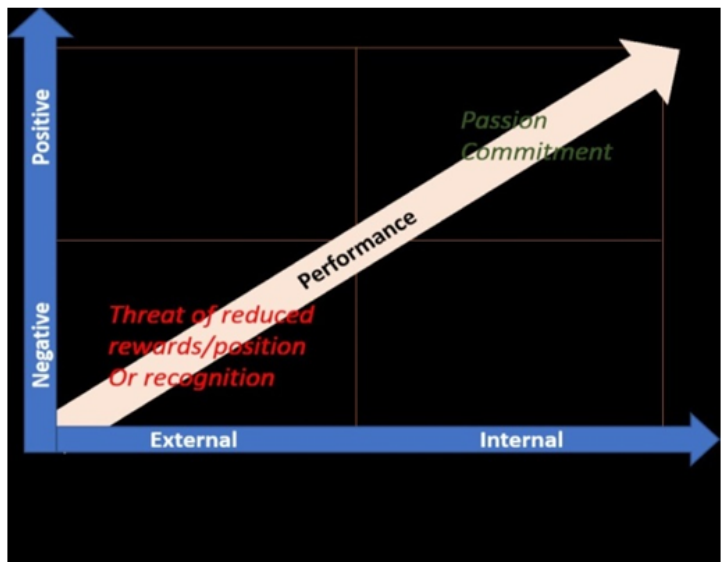

Figure 1. Positive and Negative Motivation (Kashyap 2017)

Sometimes it is necessary for the management to resort to negative motivation technique to prevent undesirable behavior among employees. This could be a temporary measure to ensure short-term motivation to some of them. However, manager should always adopt positive techniques to motivate their employees.

A small number of studies have examined the relationships between attitude, motivation and satisfaction in the agriculture and plantation sectors among Malaysian youths (Roslina et al 2016, Norehan 2016, Mohamad Amizi et al 2016, Norsida 2008). It was found that most local suburban youths preferred to work in manufacturing and retail sector rather than agricultural and plantation sector (Malaysia Human Resource Statistic 2013). They claimed that work in agricultural sector is 
burdening and tiresome (Norsida 2008). This is further supported by Walsh and Makaravy's study (2011) which reported that plantation jobs are regarded as 3D jobs (Difficult, Dirty and Dangerous) by local youths. Past studies have revealed strong negative perceptions and attitude among local youths and the reasons underlying their negativity and lack of interest. According to Frick et al., (1995), youth found that agricultural sector is unappealing due to the lack of knowledge or skill. Additionally, social issues such as drug abuse and illegal motor racing distance them further from the sector (Saifuddin, The Edge 2017).

The younger generation needs to be made aware of the opportunities waiting for them to make them significant partners in this expanding industry. Thus, this study was conducted to examine the attitudes and motivation as well as the factors underlying the lack of interest among the young FELDA generation towards the palm oil industry in Malaysia. By identifying factors that can encourage more youth involvement in the industry, opportunities for locals can be increased while dependency on foreign workers could be reduced. Besides, the purpose of the study is also to raise their awareness about the nature and future of palm oil industry in Malaysia with the hope to instill interest among Malaysian youths towards employment and a future beyond the plantation that promotes sustainability and family legacy within the industry.

\section{Methodology}

\subsection{Research Design \& Context}

This research utilized quantitative research design. A set of self-reported questionnaire was adapted from a study by Kusluvan (2000). The original questionnaire was designed for the collection of data among empoyees in the tourism industry in Turkey. For the purpose of this study, questions were revised based on the objective which is to investigate the attitude and motivation among young FELDA generation. 50 participants from 4 FELDA settlements responded to the questionnaire. The questionnaire has 3 sections: the background of the subjects, the attitude towards palm oil industry and the motivation towards palm oil industry. The questionnaire was piloted among 10 subjects and revision was made based on the responses of the pilot study. Then the actual data collection began by administering the questionnaire to 50 subjects.

\subsection{Sample Population}

Majority of the respondents (80\%) are between the age of 25 years and above (see Figure 2). The second largest group is between the ages of $22-25(16 \%)$. $64 \%$ of them are male, while $36 \%$ of them are female (see Figure 3).

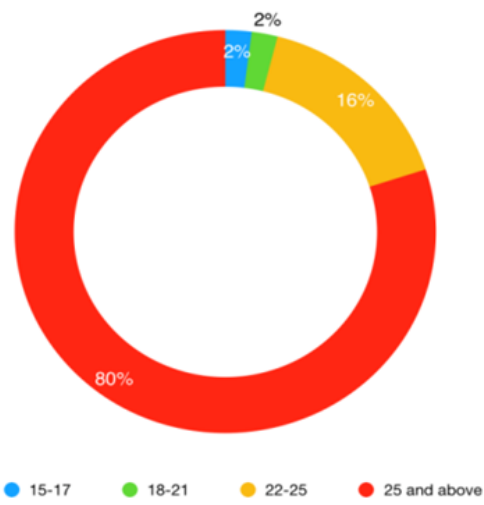

Figure 2. Age of the respondents 


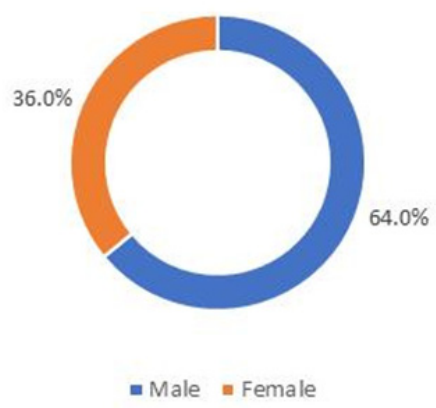

Figure 3. Gender of the respondents

Most of the respondents are from Felda Trolak Selatan (38\%) and Felda Tunggal (38\%). The rest of them are from Felda Kledang (20\%) and Felda Adela (2\%).

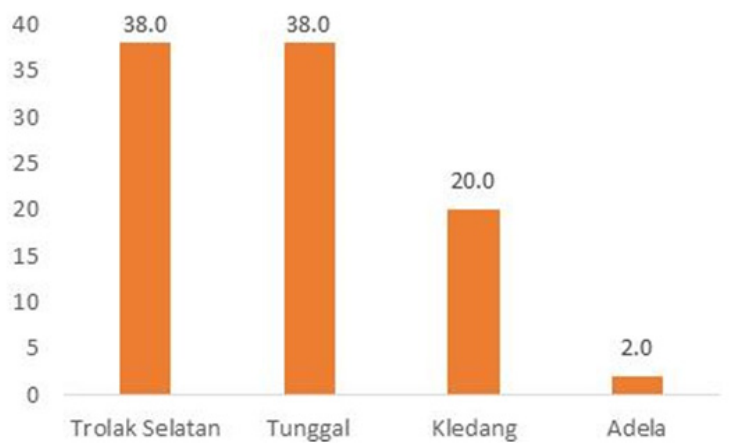

Figure 4. Locations of Respondents

$58 \%$ of the respondents have secondary level qualifications (PMR and SPM). The remaining respondents' education level is upper secondary (Diploma and STPM) (30\%) and degree level (12\%).

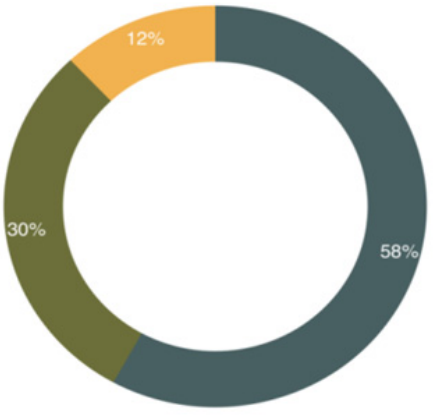

Secondary Upper Secondary Degree
(STPMDiploma) (PMRISPM)

Figure 5. Education level of Respondents 


\subsection{Research Tool}

A survey questionnaire adapted from Kusluvan (2000) was employed and translated to Bahasa Malaysia to investigate the attitudes and motivation of the respondents. The questionnaire comprises 71 questions. The first part consist of 7 items to elicit respondents' background information.

The second section consists of 64 items designed to draw out information regarding the students' attitudes and motivation towards the palm oil industry. Likert scale items ranging from "strongly disagree" to "strongly agree" were used to gauge responses. 53 items were aimed at extracting information pertaining to respondents' attitudes while another 11 items measured their motivation towards the palm oil industry.

\subsection{Research Procedures}

The questionnaire were administered to 4 FELDA locations namely, Felda Trolak Selatan, Felda Tunggal, Felda Kledang and Felda Adela through two FELDA representatives. The questionnaire were mailed back to the researchers once completed. Scores were tabulated using SPSS Windows 11.5. The statistical measures used to analyse data were ranking of mean scores, percentages and correlation coefficient. The correlation coefficient was used to investigate the correlation between some variables.

\section{Results and Discussion}

The discussion on the findings (see Figure 6) starts with the ranking of positive attitude towards the palm oil industry among the respondents.

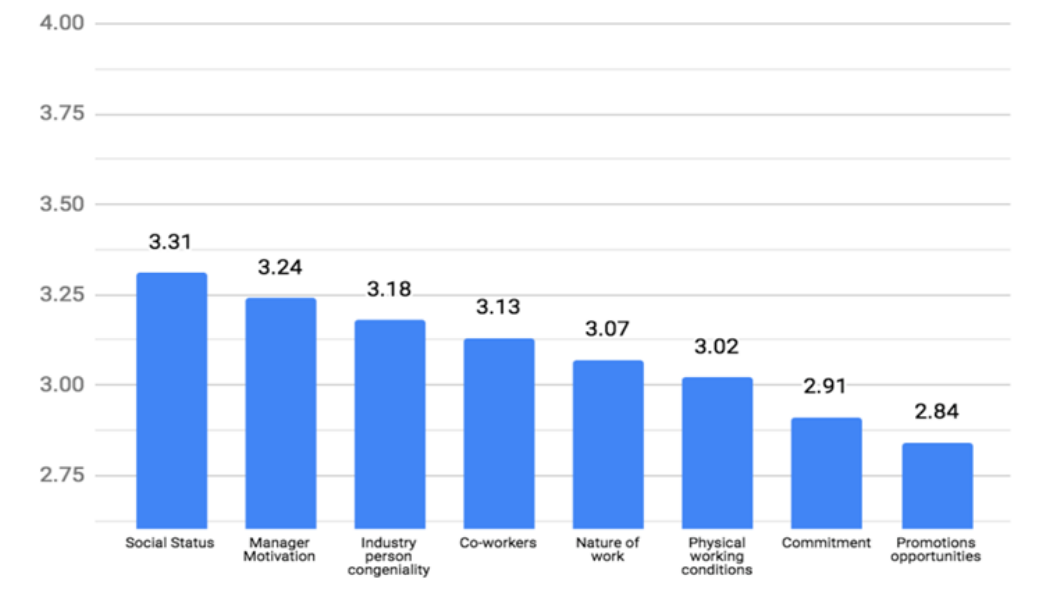

Figure 6. Mean score ranking of 8 constructs for positive attitudes

In Figure 6, we can see the ranking of 8 constructs which were found to be positive among the respondents towards the palm oil industry. Social status is ranked the highest (3.31), followed by managers (3.24), industry person congeniality (3.18), co-workers (3.13), nature of work (3.07), physical working conditions (3.02), commitment (2.91) and finally promotion opportunities (2.84). Social status is ranked the highest, showing that the respondents are confident that their family is proud of their profession in palm oil industry. Apart from that, they believed that working in palm oil industry is a respected vocation in Malaysia. As for managers, the respondents agree that the managers value their employees and they also spend much effort in supporting them in their career development. The managers tend to delegate work and always value employees' suggestions as well as behaving respectfully towards the employees. The respondents reported that the managers 
made sure that the employees participate in decisions affecting their jobs and provided appropriate training when necessary.

The next construct which was considered positive in the attitudes towards palm oil industry is industry person congeniality, where the respondents feel they can use their abilities and skills and they enjoy working in the industry. The respondents also have positive attitudes when it comes to working with co-workers. They claimed that there is cooperation amongst the employees and they can make friends easily with people working in the industry. As a result, most employees feel highly motivated.

The respondents have positive attitudes towards the nature of work in the palm oil industry. They found jobs in palm oil industry interesting, they feel that they could be independent and free, and they think that jobs in palm oil industry are worth doing. The next construct in positive attitudes is physical working condition. According to them the working conditions are generally good. As for commitment to the palm oil industry, the respondents claimed that they were interested in choosing agriculture as a vocation path. And for those who are still studying, they would choose to work in the palm oil industry when they finish their studies. They do not plan to work in another industry because they can see the potential of palm oil industry and they would recommend working in the industry to their friends and relatives.

The lowest rank of the respondents' positive attitude is promotion opportunities. Despite being the lowest ranked factor, they still believed that promotion opportunities are satisfactory in the palm oil industry.

\subsection{Negative attitudes}

The following section will discuss the ranking of negative attitudes (see Figure 7) of the respondents.

$$
4
$$

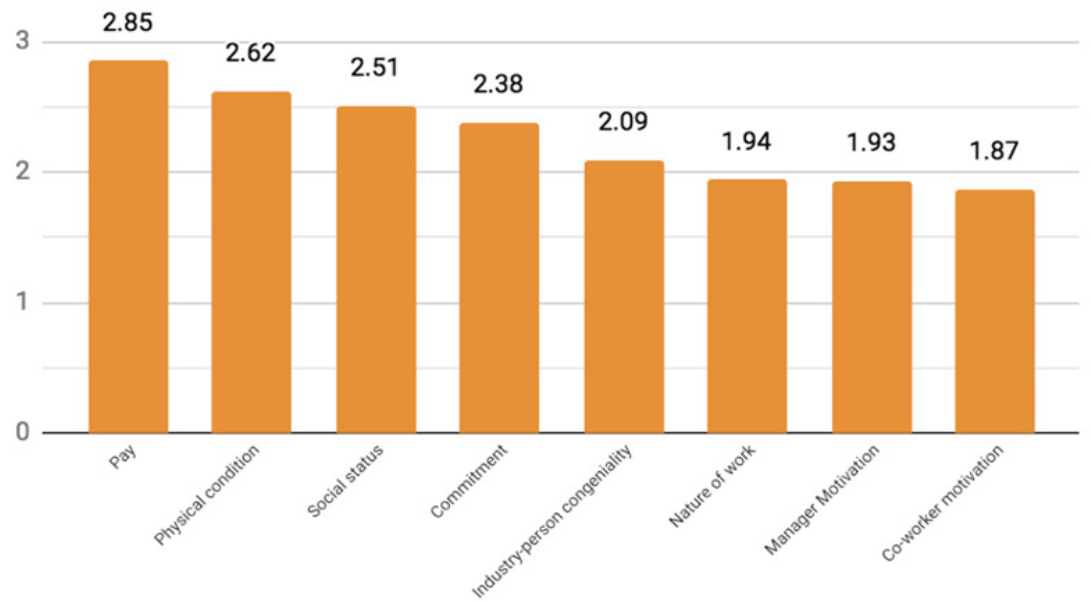

Figure 7. Mean score ranking of 8 constructs for negative attitudes

Generally, the mean scores for negative attitudes towards the palm oil industry are lower than the positive attitudes (below mean 3 ). This shows that the respondents are more positive. The highest rank in negative attitude is pay/benefits (2.85). The respondents think the pay is low for most jobs in the palm oil industry and not sufficient to lead a satisfactory life. Next ranking is physical condition (2.62). The respondents feel that the working environment is not very clean and it has a high risk of work accidents. 
The respondents also have negative attitudes when it comes to promotion activities (2.51). They are not satisfied with the way the promotions are handled. The opportunity of getting promoted to managerial positions is limited and unsystematic. Additionally, it is very difficult to get promoted if you do not have any personal contact in this industry. The next construct is the social status (2.38), in which the respondents think that those working in the palm oil industry are not valued in the society.

For the construct of commitment (2.09) to the palm oil industry, the respondents feel that the disadvantages of working in the palm oil industry outweigh the advantages. A small number of them claimed that they will not put great effort in getting a job in the palm oil industry after they finish their studies unless they become a manager or head of department.

The next rank of the negative attitude is the industry-person congeniality (1.94). Under this section the respondents claimed that they feel pressured while working in the palm oil industry. For the nature of work (1.93), the respondents feel that most jobs in the palm oil industry are low skilled, boring, stressful, exhausting and the working hours are too long. And they feel that their family lives are negatively affected for people working in the palm oil industry due to the nature of work. According to them, the working hours are unreasonable and because the nature of jobs in palm oil industry is seasonal, hence it is hard to get stable jobs.

The respondents have negative attitudes towards the managers (1.87). They believed that most managers do not have agricultural background in the palm oil industry. Apart from that, the managers do not reward employees who are doing a good job and they do not help solve employees' personal problems. They feel that there is no good relationship between managers and employees in the palm oil industry.

The lowest rank in the negative attitude is co-workers (1.81). A minority of them reported that it is not easy to get along with people working in the industry. They believed that their co-workers are not highly educated and are generally boring.

\subsection{Attitudes in relation to Age, Gender and Level of Education}

This section discusses the correlation between attitude and respondents' age, gender and level of education towards the palm oil industry. Figures 8 to 11 show the differences in mean scores of attitudes in relation to their age, gender and education level. Pearson correlation and ANOVA analyses were carried out to investigate the relationships between attitude and the 3 variables.

The overall mean scores in Graph 4 show that respondents in general have a higher positive (3.05) than negative attitude (2.33) in relation to various constructs of the industry.

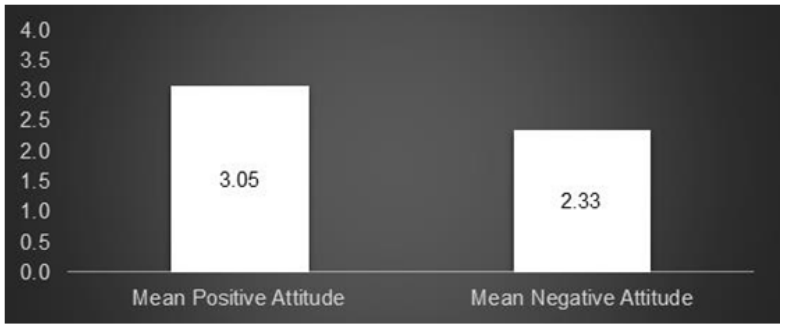

Figure 8. Mean scores for Positive and Negative Attitudes towards Palm Oil Industry

In examining the relationship between gender and attitude, the mean scores revealed that female respondents showed slightly lower positive attitude (3.00) towards the industry than the male respondents (3.09). In the case of negative attitude, the men have a lower mean score (2.32) than the women (2.33) although the difference is very small (see Figure 9 below). Results for the independent t-test however show that there was no significant difference between gender on both positive and negative attitude (see Table 1). 


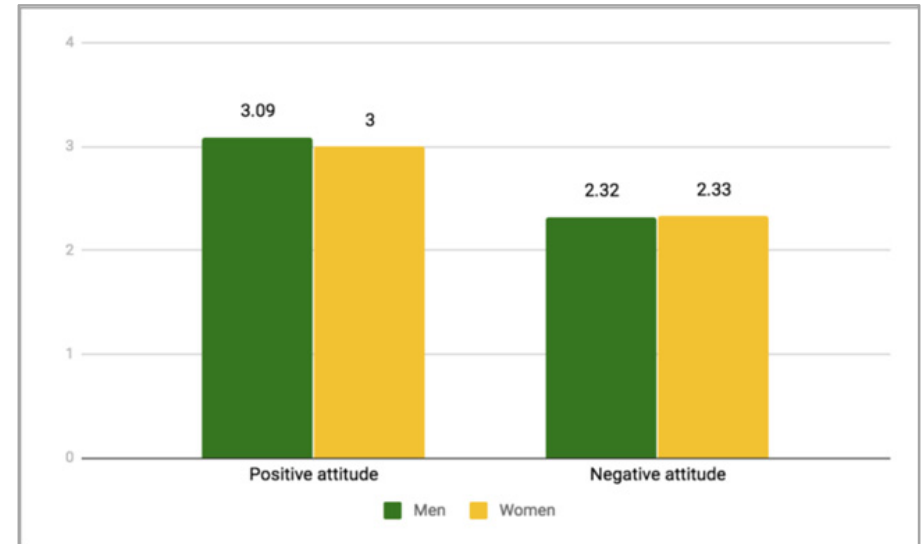

Figure 9. Gender and Mean scores for Positive and Negative Attitudes

Table 1. Independent T-test results for positive and negative attitudes

\begin{tabular}{|c|c|c|c|c|c|c|c|c|c|c|}
\hline & & \multicolumn{2}{|c|}{$\begin{array}{c}\text { Levene's Test for Equality } \\
\text { Variances }\end{array}$} & \multicolumn{7}{|c|}{ thest for Equality of Means } \\
\hline & & \multirow[t]{2}{*}{$\mathbf{F}$} & \multirow[t]{2}{*}{ Sig. } & \multirow[t]{2}{*}{$\mathrm{t}$} & \multirow[t]{2}{*}{ df } & \multirow[t]{2}{*}{ Sig (2-tailed) } & \multirow{2}{*}{$\begin{array}{c}\text { Mean } \\
\text { Difference }\end{array}$} & \multirow{2}{*}{$\begin{array}{l}\text { Std. Error } \\
\text { Difference }\end{array}$} & \multicolumn{2}{|c|}{$\begin{array}{l}95 \% \text { Conifience } \\
\text { Interval of the }\end{array}$} \\
\hline & & & & & & & & & Lower & Upper \\
\hline \multirow{2}{*}{$\begin{array}{l}\text { Mean } \\
\text { Positive } \\
\text { Attitude }\end{array}$} & $\begin{array}{l}\text { Equal variances } \\
\text { assumed }\end{array}$ & 0.185 & 0.669 & 0.932 & 47 & 0.356 & 0.08891 & 0.09539 & -0.10299 & $0.2808:$ \\
\hline & $\begin{array}{l}\text { Equal variances } \\
\text { not assumed }\end{array}$ & & & 0.996 & $39 \cdot 347$ & 0.325 & 0.08891 & 0.08922 & -0.09151 & 0.26933 \\
\hline \multirow{2}{*}{$\begin{array}{l}\text { Mean } \\
\text { Negative } \\
\text { Attitude }\end{array}$} & $\begin{array}{l}\text { Equal variances } \\
\text { assumed }\end{array}$ & 0.442 & 0.509 & -0.099 & 47 & 0.921 & -0.01021 & 0.10277 & -0.21695 & 0.19653 \\
\hline & $\begin{array}{l}\text { Equal variances } \\
\text { not assumed }\end{array}$ & & & -0.104 & 37.408 & 0.918 & -0.01021 & 0.09797 & -0.20865 & 0.18823 \\
\hline
\end{tabular}

Further analysis was carried out to assess the relationship between respondents' age and attitudes. The respondents' age were grouped into four categories - 15-17, 18-21, 22-25 and 25 and above (see Figure 10).

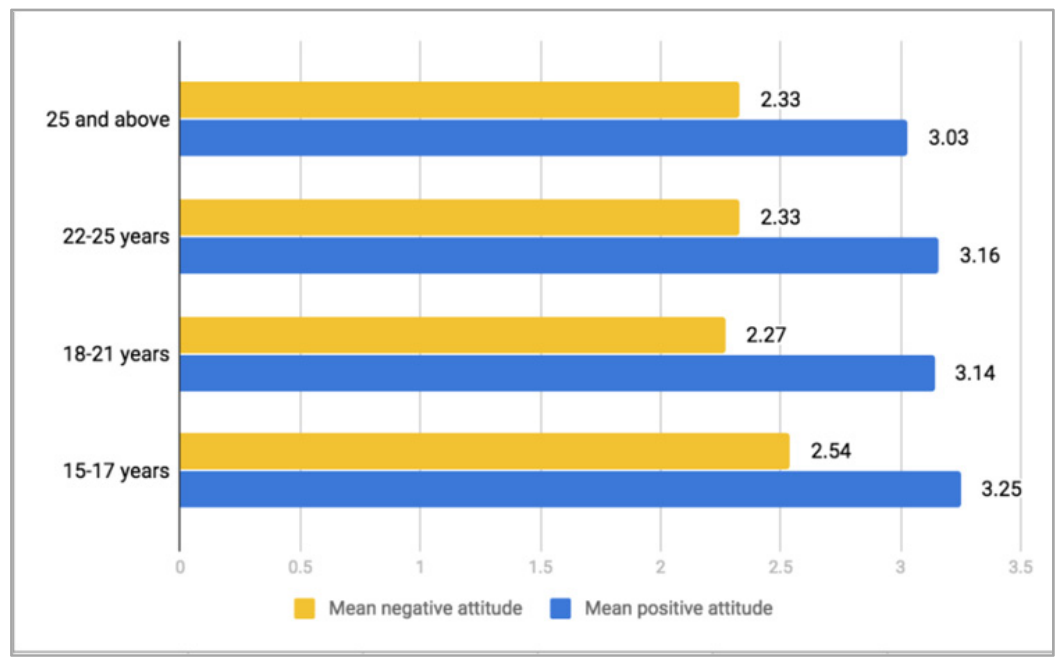

Figure 10. Age and Mean Scores for Positive and Negative Attitudes 
Results from ANOVA revealed a significant difference between positive attitude and age (see Table 2 below). On the other hand, there is no significant difference between age and negative attitude. Mean scores in Table 3 below suggest that the younger the respondents are, the more positive their attitude (3.25) is towards the industry. The results also show that respondents aged 25 and above, generated a lower mean score of positive attitude (3.03), suggesting the older they get the less positive they feel towards various constructs of the industry.

Table 2. Anova results for Positive Attitude and Age

\begin{tabular}{|l|r|r|r|r|r|}
\hline ANOVA & \multicolumn{1}{|c|}{$\begin{array}{c}\text { Sum of } \\
\text { Squares }\end{array}$} & \multicolumn{1}{c|}{ df } & \multicolumn{1}{c|}{$\begin{array}{c}\text { Mean } \\
\text { Square }\end{array}$} & \multicolumn{1}{c|}{ F } & Sig. \\
\hline $\begin{array}{l}\text { Between } \\
\text { Groups }\end{array}$ & 17.120 & 38 & 0.451 & 9.912 & 0.000 \\
\hline $\begin{array}{l}\text { Within } \\
\text { Groups }\end{array}$ & 0.500 & 11 & 0.045 & & \\
\hline Total & 17.620 & 49 & & & \\
\hline
\end{tabular}

Table 3. Anova results for Negative Attitude and Age

\begin{tabular}{|l|r|r|r|r|r|}
\hline ANOVA & $\begin{array}{c}\text { Sum of } \\
\text { Squares }\end{array}$ & \multicolumn{1}{c|}{$\mathrm{df}$} & $\begin{array}{c}\text { Mean } \\
\text { Square }\end{array}$ & \multicolumn{1}{c|}{ F } & \multicolumn{1}{c|}{ Sig. } \\
\hline $\begin{array}{l}\text { Between } \\
\text { Groups }\end{array}$ & 17.120 & 47 & 0.364 & 1.457 & 0.492 \\
\hline $\begin{array}{l}\text { Within } \\
\text { Groups }\end{array}$ & 0.500 & 2 & 0.250 & & \\
\hline Total & 17.620 & 49 & & & \\
\hline
\end{tabular}

A positive correlation was found between level of education and respondents' positive and negative attitudes towards the industry (see Table 4 below). Results revealed that there is a negative relationship between level of education and positive attitude. The higher the academic achievement, the less positive they feel towards the industry. However, a positive relationship is found between level of education and negative attitude (Pos $=-0.095 ; \mathrm{Neg}=0.080$ ). This shows that the higher the academic achievement, the more negative the attitude shown by respondents towards the industry. Correspondingly, the mean scores in Figure 11 show that those possessing tertiary qualification displayed a lower mean of positive attitude (2.90). Interestingly, higher positive attitude (3.11) was displayed among those with secondary level education. Findings indicated that the more educated the respondents are, the lower the mean for positive attitude (2.00) and the higher the mean for negative attitude (2.45). It can therefore be concluded that level of education does influence the attitudes of the respondents toward the industry (See Figure 11).

Table 4. Relationship between Attitudes and Education Level

\begin{tabular}{|l|l|c|c|c|}
\hline \multicolumn{2}{|l|}{ Correlations } & Education Level & $\begin{array}{c}\text { Mean for } \\
\text { positive attitude }\end{array}$ & $\begin{array}{c}\text { Mean for } \\
\text { negative attitude }\end{array}$ \\
\hline \multirow{4}{*}{ Education Level } & $\begin{array}{l}\text { Pearson } \\
\text { Correlation }\end{array}$ & 1 & -0.095 & 0.080 \\
\cline { 2 - 5 } & Sig. (2-tailed) & & 0.014 & 0.079 \\
\cline { 2 - 5 } & $\mathrm{N}$ & 50 & 50 & 50 \\
\hline \multirow{3}{*}{$\begin{array}{l}\text { Mean for } \\
\text { positive attitude }\end{array}$} & $\begin{array}{l}\text { Pearson } \\
\text { Correlation }\end{array}$ & -0.095 & 1 & -0.248 \\
\cline { 2 - 5 } & Sig. (2-tailed) & 0.014 & & 0.082 \\
\cline { 2 - 6 } & $\mathrm{N}$ & 50 & 50 & 50 \\
\hline $\begin{array}{l}\text { Mean for } \\
\text { negative attitude }\end{array}$ & $\begin{array}{l}\text { Pearson } \\
\text { Correlation }\end{array}$ & 0.080 & -0.248 & 1 \\
\cline { 2 - 6 } & Sig. (2-tailed) & 0.079 & 0.082 & \\
\cline { 2 - 6 } & $\mathrm{N}$ & 50 & 50 & 50 \\
\hline
\end{tabular}




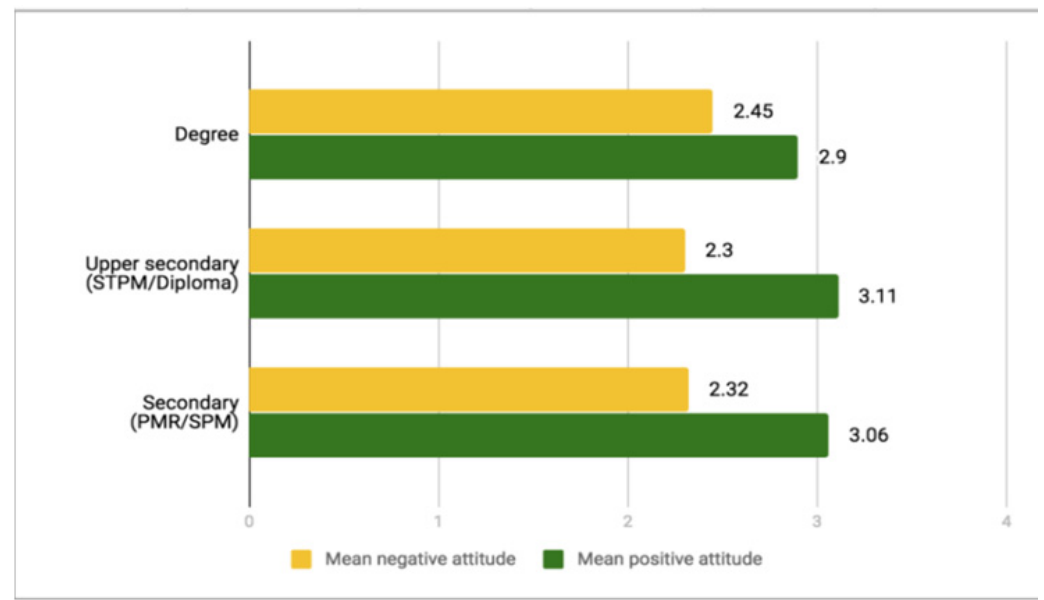

Figure 11. Education Level and Mean Scores for Positive and Negative Attitudes

\subsection{Positive and Negative Motivation}

Positive motivation in this study refers to actions that encourage the workers to contribute more to the industry while negative motivation refers to conditions that can affect workers' productivity negatively in the industry. The results will be discussed in terms of Manager and Co-workers motivation.

\subsubsection{Manager motivation (positive)}

\section{Positive manager motivation}

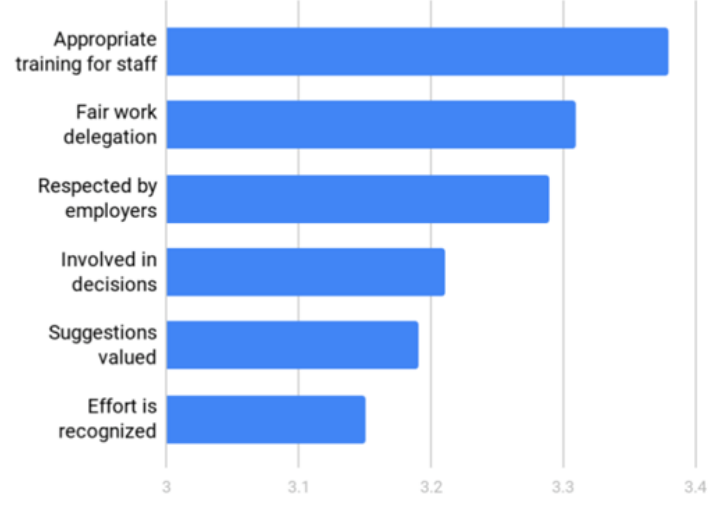

Figure 12. Positive manager motivation

In Figure 12, we can see that the highest positive manager motivation comes from providing appropriate training to staff $(3.38 \%)$. This is followed by fair work delegation for employees by managers according to expertise and skills (3.31\%). The employees also feel positively motivated if they are respected by the employers (3.29\%). Additionally, they feel appreciated when the managers involve them in decisions affecting their jobs (3.21\%). Positive motivation also arises when the employers value their employees' suggestions $(3.19 \%)$. The final factor affecting positive motivation is when managers give due value to their employees' effort (3.15\%). 


\subsubsection{Manager Motivation (negative)}

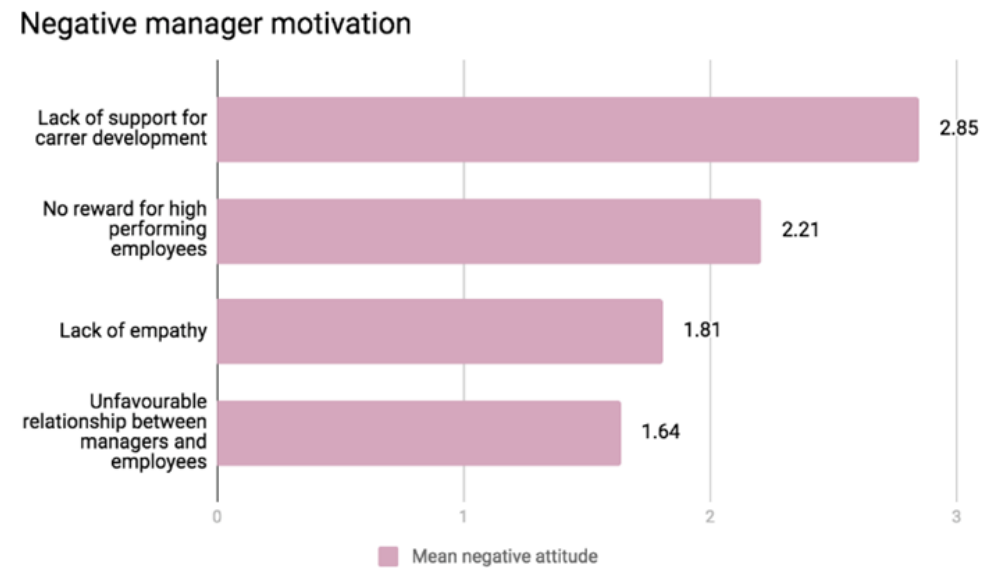

Figure 13. Negative manager motivation

For negative motivation, the results show that the highest negative motivation comes from a lack of support for employees' career development. The second factor behind negative motivation is when managers fail to reward high-performing employees. Employees will also feel disheartened if managers show lack of empathy and ignore their personal problems $(1.81 \%)$. The final factor that affects employees' motivation is when there is unfavourable relationship between managers and employees in the palm oil industry $(1.64 \%)$.

\subsubsection{Co-workers Motivation (positive)}

I can make friends easily with people working in the palm oil industry

There is cooperation amongst employees in the palm oil industry

Generally, people with educational background work in the palm oil industry

Most employees are highly motivated and enthusiastic about working in the palm oil industry

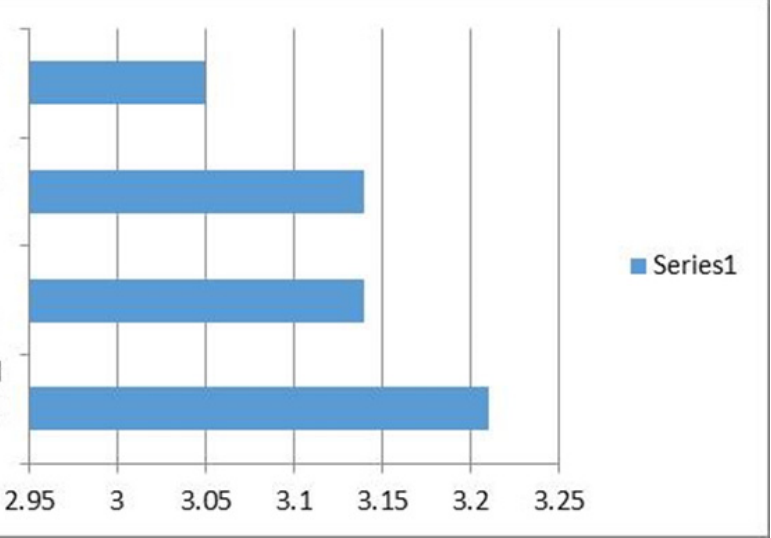

Figure 14. Positive co-worker motivation

The ranking of co-workers positive motivation is presented in Figure 14 above. The highest rank (3.21) is the perception that most employees are highly motivated and enthusiastic about working in the palm oil industry. This is followed by adequate educational background of workers who work in the palm oil industry (3.14) and cooperation amongst employees in the palm oil industry (3.14). The last factor is the friendly environment in the industry (3.05). 


\subsubsection{Co-workers Motivation (negative)}

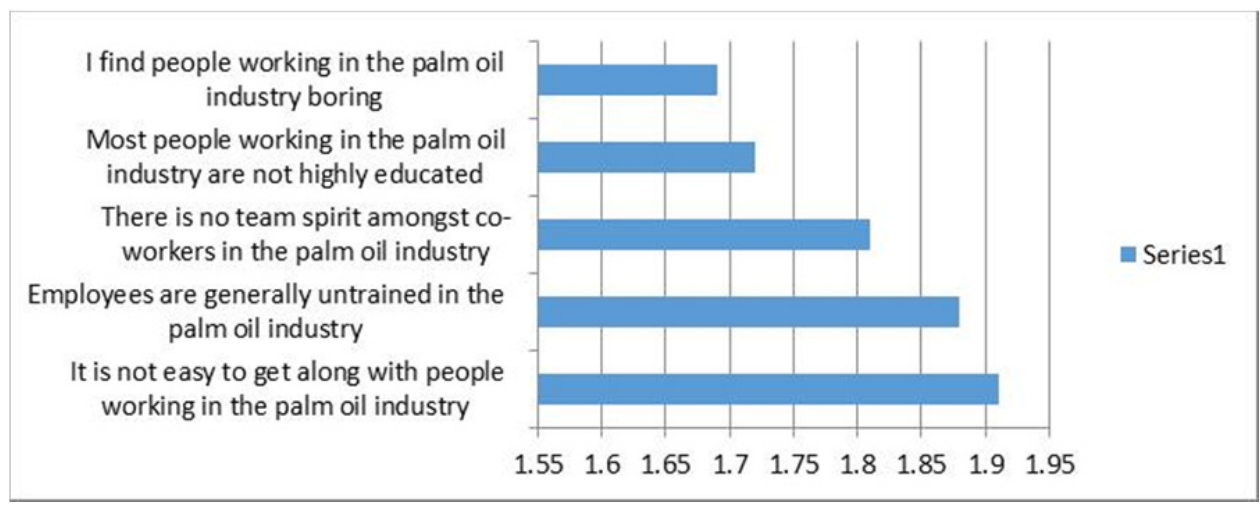

Figure 15. Negative co-worker motivation

Figure 15 shows that the highest ranked negative motivation is difficulty in getting along with other co-workers in the industry (1.91). The second negative factor is untrained workers resulting in lack of knowledge and skills in the industry (1.88). This is followed by the absence of team-spirit among co-workers (1.81). Another negative factor is inadequately educated employees in the industry (1.72). The lowest ranked factor is related to the perception that the people working in the palm oil industry are largely dull and uninteresting (1.69).

\section{Discussion and Conclusion}

The results indicate that in general, young FELDA generation have positive attitude towards the palm oil industry. They realise the importance of this industry and they have the desire to contribute towards the betterment of the industry. The findings of the study also revealed that the workers have both positive and negative attitudes and motivation towards the industry. However, the positive aspects outweigh the negative ones.

Our findings further demonstrate that with regard to ranking of positive attitude, social status is ranked the highest, followed by manager motivation and industry-person congeniality. The remaining rankings are co-worker motivation, work nature, physical working condition, commitment and promotion opportunities.

As for ranking of negative attitude, the top most ranked factor is salary/benefits, followed by physical working conditions and promotion opportunities. The remaining factors affecting negative attitudes are social status, commitment, industry-person congeniality, nature of work, manager motivation and co-worker motivation.

Our findings generally do not support the findings from Roslina et al (2016), Norehan (2016), Mohamad Amizi et al (2016) claiming that most local suburban youths preferred to work in manufacturing and retail sector rather than agricultural and plantation sector. Our results revealed that FELDA employees have more positive attitudes towards the industry and are more intrinsically motivated too. This goes against the findings made by Norsida (2008) which claimed that work in agricultural sector is burdening and tiresome. In addition, our results also contradict the findings made by Abdul Aziz \& Norhlilmatun (2013) who claimed that agriculture is not viewed as an attractive alternative due to the conventional opinion that the agriculture offers low salaries and does not promise a good future for the employees.

Interestingly, our findings indicated that there are positive attitudes towards physical working conditions in the industry, contradicting the findings made by Walsh and Makaravy's study (2011) which reported that plantation jobs are regarded as 3D jobs (Difficult, Dirty and Dangerous) by local youths. This study has generally revealed strong positive perceptions and attitudes among young 
FELDA generation and the reasons underlying their positivity and high interest.

Similar results are found with regard to motivation. Generally, the workers are more positively motivated by the cooperation given by the managers and co-workers. It appears that some of the positive factors are related to appropriate training, fair work delegation and mutual respect between managers and employees. However, the factors affecting negative motivation are lack of support in their career development and lack of reward for employee's effort. The results also indicate positive and negative motivation among co-workers. Generally, the employees are motivated and they are well educated to work in the industry.

It is hoped that the findings of this study will be able to create awareness among the youths on the opportunities waiting for them in this evolving industry. Additionally, the results of the study should be able to instil interest among Malaysian youths towards employment and a future beyond the plantation that promotes sustainability and family legacy within the industry.

\section{References}

Aziz, A., A. and Norhlilmatun, N.S. (2013). Factors that influence the interest of youths in agricultural entrepreneurship[On - line] Available http://ijbssnet.com/journals/Vol_4_No_3_March_2013/31.pd

A.-M. Masgoret \& R. C. Gardner. (2002). Attitudes, Motivation, and Second Language Learning: A MetaAnalysis of Studies Conducted by Gardner and Associates. http://wenku.baidu.com/view/7bdf737401f69e31433294db.html. [Accessed 3 July 2018[.

Ajzen, I. (1993). Attitude Theory and Attitude-behaviour Relations. In D. Krebs \& P. Schmidt, New Directions in Attitude Measurement pp 41-57). Berlin: Walter de Gruyter.

Arnold, J, Robertson, I T \& Cooper, C L. (1991). Work Psychology, Pitman, London

Baker, C. (1988). Key issues in bilingualism and bilingual education. Clevedon, Avon: Multilingual Matters.

Bloisi W., Cook C.W., Hunsaker P. L. (2003). Management and Organisational Behaviour, McGraw-Hill, pp.169208.

Brown, L. V. (2007). Psychology of motivation. New York: Nova Publishers.

Coon D, Mitterer JO. (2010). Introduction to Psychology: Gateways to Mind and Behavior With Concept Maps. Belmont. Wadsworth.

Frick, M., Birkenholz, R., Gardner, H. \& Matchmes, K., (1995). Rural and Urban Inner City High School Students: Knowledge and Perceptions of Agriculture. The Journal of Agricultural Education, 36, p. 4

Gardner, R.C. (1985). Social psychology and second language learning: The role of attitudes and motivation. London: Edward Arnold

Heckhausen,H. (1991). MotivationandAction.NewYork:Springer.

Kashyap, A. (2017). Positive and negative motivation. https://www.linkedin.com/pulse/positive-negativemotivation-amit-kashyap. [Accessed 3 July 2018].

Kusluvan, S. Kusluvan Z. (2000). Perceptions and attitudes of undergraduate tourism students towardsworking in the tourism industry in Turkey Tourism Management 21 (2000) 251-269 [accessed Jul 17 2018].

Martin, J. R., \& White, P. R. R. (2005). The language of evaluation: Palgrave Macmillan Basingstoke

Mohammad, A., et al., (2015). Perception of Local Youth in Sabah towards Career in Oil Palm Plantation. Asia Pacific Journal of Advanced Business and Social Studies, pp. 239- 246.

Mohammad Amizi A, Norehan Abdullah \& Jamal Ali. (2016). Perception of Local youths in Malaysia East Coast Region towards the career prospect in Oil Palm Plantation.

Mullins L. J. (2005). Management and Organisational Behaviour. Prentice hall. UK 7th Ed. 88(431): pp. $1052-$ 1058.

Norsida Man. (2008). Persepsi Terhadap Pertanian Dalam Kalangan Belia Tani dan Keperluan Pendidikan Pertanian. J. Pembangunan Belia Malaysia, 1, pp. 99-114.

Roslina, K., Mohd Amizi, Norehan Abdullah, Jamal Ali, Siti Aznor Ahmad. (2016). Job satisfaction among Malaysian Youth working in the palm oil plantation sector: Analysis of Attraction and Repulsion Factors. Proceeding - 3rd Kuala Lumpur International Agriculture, Forestry and Plantation. May 21 - 22, 2016.

Saifuddin A. (2017). Better education for FELDA youth. http://pnews.theedgemarkets.com/article/secondsphere-better-education-felda-youth. [Accessed 3 July 2017].

Walsh, J and Makararavy, T. (2011). Cambodian Migrants in Thailand: Working Conditions and Issues, Asian Social Science, $7(7), 23-29$

http://www.felda.net.my/index.php/en/felda/mengenai-felda accessed on 5 June 2018

Palm oil industry poised for greater growth https://www.thestar.com.my/news/nation 18 May 2017 